\title{
Penerapan Strategi Pembelajaran Metakognitif Untuk Meningkatkan Pemahaman Mendengarkan
}

\author{
Oleh: \\ Laila Rochmawati \\ Meita Maharani Sukma \\ Politeknik Penerbangan Surabaya \\ Jl. Jemur Andayani I, No. 73 Surabaya 60236 \\ Email : lailaharun@gmail.com
}

\begin{abstract}
Abstrak
Makalah ini menyelidiki tentang efek dari pelatihan strategi metakognitif pada kemampuan menyimak ceramah mendengarkan taruna di Politeknik Penerbangan (POLTEKBANG) Surabaya. Pembelajaran mendengarkan adalah hal yang sulit terutama bagi taruna yang baru saja memasuki poltekbang surabaya dan bahkan lebih cenderung menakutkan bagi taruna poltekbang Surabaya karena bahasa Inggris adalah bahasa kedua atau bahasa asing bagi mereka. Penelitian ini melibatkan 47 taruna tingkat satu dari program studi komunikasi penerbangan politeknik penerbangan Surabaya. Instrumentasi dalam penelitian menggunakan kuesioner, tes mendengarkan dan wawancara semi-terstruktur. Hasil menunjukkan bahwa taruna yang sering menggunakan strategi metakognitif ketika mendengarkan ceramah dalam bahasa Inggris mendapat skor lebih tinggi dalam uji mendengarkan. Selain itu, taruna dapat memperoleh manfaat dari pembelajaran dalam strategi mendengarkan karena ini membantu mereka dalam keberhasilan dari sisi akademis.
\end{abstract}

Kata kunci: Metakognitif; strategi pembelajaran; pemahaman mendengarkan.

\section{PENDAHULUAN}

Pelajar bahasa sering dihadapkan dengan kesulitan ketika mereka mendengarkan bahasa target. Penelitian telah ditunjukkan bahwa kesulitan-kesulitan ini termasuk seberapa cepat seseorang berbicara (Conrad, 1989; Blau, 1990; Zhao, 1997), kata-kata yang digunakan (Johns dan Dudley-Evans, 1980; Kelly, 1991), fitur fonologis (Henrichsen, 1984; Matter, 1989) dan latar belakang pengetahuan (Long, 1990; Chiang dan Dunkel, 1992). Brown (1995) lebih lanjut berpendapat bahwa kesulitan mendengarkan juga terkait dengan tingkat tuntutan kognitif yang dibuat oleh isi teks. Laporan dalam ini artikel adalah bagian dari studi yang lebih besar tentang pengaruh pembelajaran strategi metakognitif pada kuliah pemahaman mendengarkan bahasa kedua. Dalam beberapa tahun terakhir, ada minat yang meningkat dan penelitian tentang perlunya keterampilan mendengarkan yang efektif dan strategi untuk mahasiswa universitas ESL yang belajar di lembaga berbahasa Inggris (Hyon, 1997) karena bahasa Inggris telah menjadi bahasa utama dalam dunia pendidikan tinggi dan universitas (Long \& Richards, 1994). Keterampilan pemahaman mendengarkan yang efektif sangat penting untuk kesuksesan mahasiswa dalam bidang akademisi (Benson, 1994; Dunkel, 1991; Flowerdew, 1992, 1994; Vandergrift, 2004). Namun, Mendelsohn (2002) berpendapat bahwa keterampilan mendengarkan siswa tidak cukup memungkinkan untuk berkembang secara efektif dengan mengekstrak informasi konten dari kuliah. Bahkan, dosen sering menganggap bahwa siswa akan mengembangkannya keterampilan mendengarkan melalui "osmosis dan tanpa bantuan" 
(Mendelsohn, 1984). Dalam analisis masalah yang dihadapi oleh siswa Malaysia yang belajar di UiTM, Abdul Aziz \& Ismail (2005) menemukan bahwa para siswa ini kekurangan keterampilan yang diperlukan untuk belajar melalui ceramah di media bahasa Inggris. Peneliti menunjukkan bahwa kuliah mendengarkan adalah bagian utama dari studi universitas (Richards, 1983; Benson, 1989 di Flowerdew, 2003; Morell, 2004). Benson (1994) memberi label ceramah sebagai "ritual pusat universitas budaya". Sebuah penelitian oleh Ferris dan Tagg (1995 dikutip dalam Hyon, 1997) menunjukkan bahwa mode pembelajaran kuliah umum adalah mode pembelajaran yang paling banyak di lebih dari 230 universitas dan fakultas perguruan tinggi. Namun, selama kuliah, siswa ESL dihadapkan dengan kesulitan yang lebih besar karena mereka harus memahami materi pelajaran yang disampaikan dalam bahasa Inggris yang mana mereka juga bersaing dengan hambatan lain yang dalam mendengarkan ceramah. Ini mengarah pada kesulitan pemahaman ketika taruna mendengarkan ceramah akademis. Mason (1994) meneliti strategi pemahaman ceramah dari 26 mahasiswa pascasarjana belajar di media bahasa Inggris untuk pertama kalinya. Hasil penelitian mengungkapkan bahwa ada berbagai masalah di tingkat yang berbeda dalam memahami kuliah. Meskipun mendengarkan telah diajarkan di banyak program bahasa, para ahli masih percaya bahwa banyak penelitian perlu dilakukan untuk mengaktifkan keterampilan pengajaran kelas yang lebih efektif (Anderson dan Lynch 1988; Buck 1995; Mendelsohn 1998; Goh, 2000; Vandergrift 2004). Mulai dari tahun 1960-an, pembelajaran mendengarkan mulai menerima perhatian, bagaimanapun, itu banyak dipengaruhi oleh penelitian dalam membaca dan menulis (Brown, 1987). Dengan popularitas metodologi Pengajaran Bahasa Komunikatif (CLT), mendengarkan mulai mendapatkan kepentingan, Metode CLT menekankan perlunya mengajar mendengarkan untuk komunikasi lisan yang efektif. Dengan perkembangan metodologi yang cepat dibantu komputer dan media, lebih banyak ahli mulai melihat kegiatan mendengarkan sebagai keterampilan bahasa yang penting untuk dikembangkan. Hal ini mengakibatkan meningkatnya penelitian tentang keterampilan menyimak dan prosesnya.

Penelitian oleh Rubin (1994), Lynch (1998), Vandergrift (2004), Flowerdew and Miller (2005), Macaro, Graham dan Vanderplank (2007) dan Goh (2008) telah menarik perhatian kami untuk menggunkan pendekatan baru dalam mengajar mendengarkan. Dalam penelitian ini juga ditujukan untuk perkembangan di bidang psikologi kognitif. Salah satunya penelitian di bidang psikologi kognitif adalah pendekatan metakognitif (Chamot, 1995; Mendelsohn, 1995; 1998; Vandergrift, 2004 dan Goh, 2008). Pendekatan metakognitif bertujuan untuk melatih peserta didik untuk menerapkan strategi yang efektif untuk mengatasi tuntutan mendengarkan (Mendelsohn, 1998). Meskipun penelitian ini terbatas pada bidang efek strategi metakognitif pada mendengarkan, bukti dari membaca dan menulis menunjukkan fakta bahwa strategi metakognitif membantu siswa dalam mengelola pembelajaran mereka supaya lebih efektif, karenanya, mereka dapat memaksimalkan informasi yang diterima dan ini dapat digunakan untuk meningkatkan kinerja tugas yang dibutuhkan mereka. Wenden (1998) berpendapat bahwa pelajar yang menggunakan kemampuan metakognitif tampaknya memiliki kelebihan-kelebihan berikut atas para pelajar yang tidak mengetahui peran menguntungkan yang dimainkan oleh metakognisi pembelajaran bahasa:

1. Mereka adalah pelajar yang lebih strategis.

2. Tingkat kemajuan mereka dalam belajar serta kualitas dan kecepatan keterlibatan kognitif mereka lebih cepat.

3. Mereka yakin akan kemampuan mereka untuk belajar. 
4. Mereka tidak ragu untuk mendapatkan bantuan dari teman sebaya, guru, atau keluarga bila diperlukan.

5. Mereka memberikan penilaian yang akurat tentang mengapa mereka berhasil belajar.

6. Mereka berpikir dengan jelas tentang ketidakakuratan ketika kegagalan terjadi selama suatu kegiatan.

7. Taktik mereka sesuai dengan tugas belajar dan penyesuaian dibuat untuk mencerminkan keadaan yang berubah.

8. Mereka menganggap diri mereka sebagai pembelajar yang berkelanjutan dan dapat berhasil mengatasi situasi baru.

Dalam studinya, Vandergrift (2004) menggunakan teknik yang disebut urutan metakognitif memfasilitasi penggunaan subjeknya strategi metakognitif selama mendengarkan. Hasil penelitian menunjukkan bahwa proses ini bermanfaat bagi subjek melalui peningkatan kesadaran mereka tentang penggunaan strategi dan menyediakan semacam perancah ketika subjek sedang melakukan tugas mendengarkan. Penelitian Vandergrift tampaknya mendukung penggunaan strategi-strategi ini untuk memperbaiki pemahaman taruna serta memotivasi mereka untuk belajar. Artikel ini meneliti sikap dan pemahaman taruna dalam mendengarkan pada awal masuk politeknik dan strategi metakognitif yang mereka gunakan untuk membantu pemahaman kuliah mereka.

\section{METODE PENELITIAN Studi}

Penelitian ini menggunakan metodologi penelitian kuantitatif dan kualitatif. Data diperoleh dari pre dan post tes, kuesioner dan wawancara semi-terstruktur dengan subyek.

\section{Subjek}

Subjek penelitian adalah 47 taruna tingkat satu yang mengambil gelar ahli madya kounikasi penerbangan di sebuah politeknik penerbangan Surabaya. Semua taruna berasal dari latar belakang yang tidak berbahasa Inggris dan bahasa Inggris adalah bahasa kedua atau asing bahasa bagi mereka. Bagi mereka, sebagian besar komunikasi bahasa Inggris terbatas pada pelajaran bahasa Inggris di sekolah mereka saja. Taruna tahun pertama dipilih karena mereka menghadapi tantangan yang lebih besar dalam memahami kuliah seperti kebanyakan sekolah di Indonesia masih mengadopsi gaya belajar tradisional yang berpusat pada guru dan berorientasi pada ujian. Secara umum mereka menemukan pemahaman mendengarkan di lingkungan bahasa Inggris akademik cukup sulit. Para taruna terdiri dari 13 taruna perempuan dan 34 taruna lakilaki berusia antara 18 dan 23 tahun. Semua 47 taruna dalam penelitian ini terdaftar sebagai taruna pada program studi komunikasi penerbangan.

\section{Instrumentasi}

Untuk menentukan apakah para taruna telah mendapat manfaat yang signifikan dari program intervensi 10 minggu, taruna diminta untuk mengikuti pre-test sebelum mereka menjalani strategi pelatihan. Setelah strategi 10 minggu pelatihan, mereka diminta lagi untuk mengikuti tes serupa. Tes itu diadaptasi dari Tes Bahasa Inggris sebagai Bahasa Asing (TOEFL) mendengarkan bagian pemahaman. Alasan mengapa tes itu berdasarkan TOEFL adalah karena fakta bahwa TOEFL adalah tes bahasa Inggris yang paling banyak digunakan di dunia karena digunakan lebih dari perguruan tinggi, universitas dan agensi di seluruh dunia dan itu termasuk bagian tentang mendengarkan ceramah kehidupan nyata. Itu tes terdiri dari pertanyaan pilihan ganda dan pertanyaan inferensi berdasarkan ide utama konten disajikan dalam kuliah. Tes sudah 
diujicobakan dengan kelompok taruna yang serupa dan divalidasi oleh a panel ahli sebelum aplikasi mereka. Analisis tes-tes ulang menunjukkan cronbach-alpha 0,903. Setelah 47 taruna duduk untuk post-test di akhir strategi mendengarkan ceramah metakognitif 10-minggu pembelajaran, nilai rata-rata dari pre dan post tes dibandingkan untuk menentukan apakah ada yang signifikan perbedaan di antara mereka. Ini akan menunjukkan apakah ada perbaikan yang bisa dikaitkan dengan penerapan strategi mendengarkan yang telah dipelajari taruna selama pelatihan. Setelah tiga minggu hadir kuliah dalam bahasa Inggris di poltekbang, subjek diminta untuk menjawab kuesioner strategi mendengarkan ceramah metakognitif. Kuesioner diadaptasi dari Vandergrift et al. (2006) Metacognitive Awareness Listening Questionnaire (MALQ). MALQ telah digunakan sebagai alat untuk dimunculkan kesadaran taruna tentang proses mendengarkan dan untuk meningkatkan penggunaan strategi pemahaman mandiri (Coşkun, 2010). Item kuesioner terkait dengan lima faktor metakognitif yang terkait dengan mendengarkan strategi: pengetahuan pribadi subyek tentang mendengarkan, strategi metakognisi evaluasi perencanaan, mental strategi penerjemahan, mengarahkan perhatian dan strategi pemecahan masalah. Kuesioner dianalisis menurut faktor-faktor ini menggunakan penghitungan frekuensi. Sementara itu, wawancara pertama kali ditranskripsi dan kemudian dianalisis secara induktif dan deduktif.

\section{Tahapan penelitian - MetSI}

Perlakuan yang digunakan dalam penelitian ini adalah Metacognitive Strategy Training Instruction (MetSI) berdasarkan pada Brown's Strategi Metakognitif. Selama program MetSI, 47 taruna menjalani 10 minggu intensif modul strategi mendengarkan metakognitif yang bertujuan untuk meningkatkan kemampuan mendengarkan ceramah dan metakognitif mereka strategi. Dasar pemikiran untuk program 10 minggu adalah agar program berakhir pada akhir semester. Minggu pertama digunakan untuk kegiatan ice-breaking dan menggunakan pre-test untuk para taruna. Minggu terakhir semester digunakan untuk mengumpulkan data melalui kerja pasca-tes dan wawancara. Penjelasan ini meringkas program Pelatihan Strategi Metakognitif: Metacognitive Strategy Instruction (MetSI) terdiri dari tugas mendengarkan di mana taruna mendengarkan banyak teks audio, termasuk mendengarkan cerita serta ceramah akademis. Program termasuk demonstrasi dan contoh sehingga taruna akan melihat strategi dalam tindakan. Setiap modul pengajaran disajikan dibagi menjadi strategi spesifik yang mendasari bahwa taruna akan memiliki kesempatan untuk berdiskusi dan berlatih. Setiap pelajaran terdiri dari tiga tahap utama: pra-, saat dan pasca-mendengarkan. Di tahap pra-mendengarkan, taruna diberikan pertanyaan atau diskusi pra-mendengarkan dan pengenalan kosakata baru. Pra-mendengarkan kegiatan termasuk revisi dan presentasi item bahasa, dan perencanaan dan persiapan untuk suatu kegiatan. Selama tahap "sedang mendengarkan", taruna melakukan kegiatan atau tugas yang bertujuan mempraktekkan strategi dan mengembangkan keterampilan mendengarkan. Setiap pelajaran terdiri dari tinjauan cepat termasuk dialog atau jenis latihan audio lainnya.

Instruktur juga mengajukan pertanyaan dan menunjukkan strategi pada tahap ini. Akhirnya, di tahap pasca-mendengarkan, para taruna diberikan latihan untuk latihan strategi. Para taruna praktik lebih lanjut untuk mengkonsolidasikan, memperluas dan meninjau bahasa, baik dalam konteks yang berbeda atau untuk memperoleh hasil pada lembar kerja mendengarkan mereka selama posting tahap mendengarkan. Untuk meningkatkan kesadaran taruna tentang strategi yang digunakan pada setiap tahap, dorongan, pertanyaan dan teknik dan strategi pemodelan harus digunakan oleh instruktur secara konsisten. Ini untuk mendemontrasikan, mendiskusikan tentang pembelajaran dan membantu taruna merefleksikan apa yang telah mereka 
lakukan, bagaimana cara mereka melakukannya dan seberapa baik mereka melakukannya. Wenden (1985) menyoroti fakta bahwa pengajar perlu memperluas peran mereka dengan memngambil peran sebagai pembimbing, memberikan pertanyaan yang termasuk memberikan kepada taruna tentang pembelajaran bahasa dan apa yang mereka lakukan dan bagaimana cara mereka akan melakukannya.

\section{HASIL PENELITIAN}

Pra dan Post Tes

Hasil perbandingan pre-test dan post-test taruna menggunakan uji-T independen. Itu analisis kinerja keseluruhan taruna untuk tes pra dan pasca ditunjukkan pada Tabel 1. Skor menunjukkan bahwa taruna memperoleh skor rata-rata lebih tinggi dalam post-test dibandingkan dengan skor pre-test. Skor rata-rata diperoleh dari pra dan pasca tes adalah 61,00 dan 75,26 masing-masing menghasilkan perbedaan rata-rata 14,265. Hasil juga menunjukkan bahwa total skor untuk tes pasca taruna berbeda secara signifikan pada $\mathrm{p}<0,05$ : $\mathrm{t}=4,545, \mathrm{p}=0,000$ (sig. 2 tailed). Oleh karena itu, hasil menunjukkan bahwa taruna menunjukkan tingkat perbaikan yang lebih tinggi setelah diterapkan strategi metakognitif.

Tabel 1. Pra dan Post Tes

Table 1: T-test

\begin{tabular}{lllll}
\hline & Mean $(\%)$ & Std Deviation & $\mid$ t|-value & p-value \\
\hline Pre test mark & 61.00 & 13.887 & & \\
Post test mark & 75.26 & 14.469 & & p-value \\
& Mean & Std deviation & $|\mathrm{t}|$-value & 0.000 \\
Pre test* post test mark & -14.265 & 18.301 & 4.545 & \\
\hline
\end{tabular}

\section{Kuesioner dan Wawancara}

Item kuesioner dianalisis sesuai dengan faktor-faktor metakognitif yang terkait dengan strategi mendengarkan:

1. pengetahuan pribadi tentang mendengarkan,

2. strategi metakognitif evaluasi-perencanaan,

3. strategi penerjemahan mental,

4. perhatian diarahkan dan

5. strategi pemecahan masalah.

Analisis kuesioner menunjukkan bahwa menggunakan pengalaman dan pengetahuan adalah strategi utama untuk memfasilitasi pemahaman mendengarkan (rata-rata $=3,136, \mathrm{SD}=$ $0,720)$.

\section{Pengetahuan Pribadi}

Tabel 2 di bawah ini menjelaskan temuan tentang pengetahuan secara pribadi taruna. Temuan mengungkapkan bahwa hampir 47\% Responden menemukan kegiatan mendengarkan sebagai keterampilan bahasa yang paling sulit dibandingkan dengan membaca, menulis dan berbicara. Sebagian besar subyek (65\%) juga memandang mendengarkan sebagai tantangan. 
Tabel 2. Pengetahuan Pribadi

Table 2: Personal Knowledge

\begin{tabular}{lc}
\hline Item & $\begin{array}{c}\text { Percentage } \\
(\%)\end{array}$ \\
\hline I find that listening to English is more difficult than reading, speaking, or writing in English. & 47 \\
I feel that listening comprehension in English is a challenge for me. & 65 \\
\hline
\end{tabular}

Temuan ini selanjutnya dijabarkan oleh responden selama sesi wawancara dengan subjek penelitian. Dalam sesi wawancara meskipun mengungkapkan bahwa beberapa taruna merasa berbicara lebih sulit daripada mendengarkan karena mereka merasa bahwa mereka dihakimi setiap kali mereka berbicara dalam bahasa Inggris. Di sisi lain, karena sifat alami dari proses mendengarkan, subjek tidak merasa bahwa mereka dihakimi oleh kemampuan mendengarkan mereka:

S5: "Berbicara paling sulit karena kadang-kadang ketika kita berbicara dalam bahasa Inggris, kita berpikir dalam bahasa Inggris benar, untuk datang dengan kata-kata dalam bahasa Inggris cukup sulit. "

Sesi wawancara juga mengungkapkan bahwa banyak taruna yang tidak merasa keterampilan mendengarkan dalam bahasa Inggris penting bagi mereka untuk unggul di sekolah meskipun membaca sering ditekankan oleh pengajar:

S1 : "Di sekolah saya, guru selalu menekankan pada membaca - tidak terlalu banyak mendengarkan. Mereka baru saja melakukan pendalaman di kelas .sampai kami harus melakukan TOEFL, kemudian kami mendengarkan. Mereka juga memfokuskan pada tata bahasa, tidak mendengarkan ..."

S3: "Saya tidak pernah belajar cara mendengarkan. Di sekolah mereka tidak mengajar kami mendengarkan. Saya baru saja melalui pelajaran."

Namun, wawancara juga mengungkapkan bahwa persepsi subjek berubah ketika mereka memasuki universitas sebagai mereka menghadapi kesulitan dalam memahami kuliah yang disampaikan dalam bahasa Inggris.

S1: “... di kelas, teman-teman saya dan saya tertinggal karena sulit bagi kami untuk mengerti dan juga sulit bagi dosen untuk menyelesaikan silabus ... Para dosen perlu mengklarifikasi semuanya untuk membuat kami mengerti, jadi kami memiliki

waktu yang sulit (menyelesaikan silabus)"

S3: "Saya merasa sangat sulit karena saya tidak berlatih berbicara bahasa Inggris dengan teman saya (di sekolah) ... Saya pikir kita

harus memasukkannya (mengajar mendengarkan) di sekolah karena itu sangat membantu ... karena di Malaysia mereka (sekolah) tidak

mengajar mendengarkan ... Saya pikir ini penting karena ini adalah salah satu keterampilan untuk membantu belajar "

Temuan di atas dikuatkan dengan temuan penelitian lain bahwa pembelajar bahasa tidak memandang strategi sebagai hal penting dalam keterampilan mendengarkan dan sebagian besar pembelajar bahasa tidak memiliki kesadaran bahwa strategi ini dapat secara positif mempengaruhi proses mendengarkan mereka (Oxford et. al., 1990; Cohen, 2000; Vandergrift, 1990, Coşkun, 2010).

\section{Strategi Metakognitif Evaluasi Perencanaan}

Penelitian telah menunjukkan manfaat dari menyiapkan dan meninjau topik yang dipelajari dalam sebuah ceramah. Studi oleh Rost (1994) dan Dunkel dan Davis (1994) menunjukkan bahwa pengetahuan sebelumnya dapat membantu taruna dalam memahami pelajaran mereka 
lebih efektif. Demikian pula, sebuah studi oleh Flowerdew dan Miller (1992) menunjukkan bahwa taruna dengan Pengetahuan latar belakang topik kuliah dapat berhubungan lebih efektif dengan konten kuliah. Sebaliknya, Analisis yang ditampilkan pada Tabel 3 di bawah ini, menunjukkan bahwa dalam hal perencanaan dan strategi evaluasi, subjek melakukannya tidak sepenuhnya memanfaatkan strategi-strategi ini untuk membantu dalam pemahaman kuliah mereka.

Tabel 3. Strategi Metakognitif Evaluasi Perencanaan

\begin{tabular}{ll} 
Table 3: Planning-evaluation Metacognitive Strategies \\
\hline Item
\end{tabular}

Analisis menunjukkan bahwa hanya 55\% dari subyek merencanakan ke depan tentang bagaimana rencana mereka yang akan mendengarkan ceramah. Ini dikuatkan oleh komentar dari subjek bahwa mereka tidak sadar akan pentingnya mempersiapkan mendengarkan dalam bentuk ceramah. Banyak subjek juga berkomentar bahwa mereka tidak tahu dan tidak pernah diajarkan tentang cara mempersiapkan ceramah. Wawancara dengan subjek juga mengungkapkan bahwa mereka tidak merasa bahwa mereka perlu membaca catatan kuliah atau buku teks persiapan kuliah.

S3: "Saya baru masuk ke ruang kuliah ..."

S5: "Saya tidak menyiapkan apa pun, saya hanya pergi (ke ceramah)"

S1: "Kadang-kadang, saya akan 'google' (tentang topik) sebelum kuliah, tetapi hanya kadangkadang ..."

Temuan di atas dikuatkan dengan temuan berikutnya bahwa hanya sebagian kecil subjek (33\%) mengatakan bahwa mereka memikirkan teks serupa sebelum kuliah sementara (61\%) dari subyek setuju bahwa mereka memiliki tujuan dalam pikiran sementara mendengarkan ceramah. Sementara itu, 59\% dari subyek menyatakan bahwa setelah mendengarkan ceramah, mereka merefleksikan bagaimana mereka mendengarkan, dan bagaimana mereka bisa melakukannya dengan strategi berbeda di lain waktu. Namun, hanya $44 \%$ dari subyek mengatakan bahwa mereka secara berkala bertanya sendiri jika mereka puas dengan tingkat pemahaman mereka sepanjang kuliah.

Wawancara dengan subyek sependapat dengan temuan di atas:

S2: "... Saya tidak berpikir bagaimana saya melakukannya (dalam ceramah)"

S6: "... Saya bertanya kepada teman-teman saya jika saya tidak mengerti, kadang-kadang saya meminta pada saat ceramah tetapi setelahnya (ceramah)"

S1: "Saya bertanya kepada teman saya setelah kelas jika saya tidak mengerti tetapi saya tidak suka untuk menghentikan kuliah. Tetapi sebagian besar waktu saya lupa bertanya pada teman saya (setelah ceramah) ... Kadang-kadang, kita harus pergi ke kuliah berikutnya "

Alasan mengapa subjek tidak mencerminkan atau memeriksa pemahaman mereka dapat disebabkan oleh fakta bahwa subjek berada tidak menyadari strategi ini. Di atas itu mereka tidak sadar akan pentingnya meninjau catatan kuliah setelah kuliah dan beberapa subyek berpendapat bahwa mereka tidak punya waktu untuk melakukannya. Wawancara juga mengungkapkan bahwa hanya subyek tertentu yang meninjau catatan kuliah mereka sebelum mereka mengikuti tes. 


\section{Strategi Penerjemahan Mental}

Meskipun metode pembelajaran bahasa kedua dan asing mengasumsikan bahwa taruna harus berpikir sebanyak mungkin dalam bahasa target, penelitian di bidang membaca dan menulis telah menunjukkan bahwa terjemahan selektif masuk Bahasa asli dapat membantu dalam pemahaman taruna (Cohen dan Allison, 2000). Ini sesuai dengan melihat bahwa menterjemahkan adalah aktivitas kognitif yang kompleks dalam proses pemecahan masalah (Wilss, 1996). Temuan dari studi ini menunjukkan bahwa strategi penerjemahan mental juga digunakan oleh subjek untuk membantu pemahaman mereka kuliah. Tabel 4 merangkum hasil analisis:

Tabel 4. Strategi Penerjemahan Mental

Table 4: Mental Translation Strategies

\begin{tabular}{lc}
\hline Item & $\begin{array}{c}\text { Percentage } \\
(\%)\end{array}$ \\
\hline I translate word by word, as I listen to a lecture. & 49 \\
I translate key words as I listen to a lecture. & 62 \\
\hline
\end{tabular}

Untuk meningkatkan pemahaman mereka, $62 \%$ dari subjek menyatakan bahwa mereka hanya menerjemahkan kata kunci untuk membantu mereka memahami sebuah kuliah. Namun, hanya 49\% dari subyek mengatakan bahwa mereka menerjemahkan kata demi kata ketika mereka mendengarkan sebuah kuliah sambil mendengarkan ceramah. Ini mungkin karena fakta bahwa penerjemahan kata demi kata sulit dilakukan dan menuntut tingkat konsentrasi yang tinggi untuk mempertahankan untuk jangka waktu yang lama.

\section{Perhatian yang diarahkan}

Kemampuan taruna untuk mengarahkan perhatian mereka pada subjek adalah strategi penting untuk memungkinkan pemahaman terutama di kuliah panjang. Ini didukung oleh Kaplan dan Berman (2010) yang menunjukkan bahwa kemampuan untuk secara sadar mengontrol perhatian kita adalah kapasitas kunci untuk fungsi eksekutif (perencanaan, pemikiran) dan selfregulasi (kontrol pikiran dan perilaku). Analisis kuesioner menunjukkan bahwa subjek itu Mampu utalisasi strategi ini. Hasil dari strategi perhatian terarah yang digunakan oleh subjek dijelaskan pada Tabel 5 di bawah:

Tabel 5. Perhatian yang diarahkan

Table 5: Directed Attention

\begin{tabular}{lc}
\hline Item & $\begin{array}{c}\text { Percentage } \\
(\%)\end{array}$ \\
\hline I focus harder on the text when I have trouble understanding a lecture & 80 \\
When I have difficulty understanding what I hear, I give up and stop listening. & 21 \\
When my mind wanders when listening to a lecture, I recover my concentration right & 73 \\
away. & \\
\hline
\end{tabular}

Banyak subjek yang diwawancarai menyatakan bahwa mempertahankan konsentrasi dan tetap fokus adalah yang paling penting rintangan sulit untuk diatasi selama kuliah.

S2: "Saya selalu melamun selama kuliah, terutama jika itu membosankan atau saya tidak bisa mendengar dosen."

S3: "Berkonsentrasi sulit ... mungkin saya hanya melamun ketika saya tidak mengerti ... "

Namun, analisis kuesioner menunjukkan bahwa subjek menggunakan strategi perhatian diarahkan untuk mengatasi masalah-masalah ini. Ketika dihadapkan pada masalah pemahaman 
kuliah, mayoritas subjek (80\%) akan lebih fokus pada teks. Di atas ini, mayoritas subyek (79\%) mengatakan bahwa mereka tidak menyerah dan berhenti mendengarkan ketika menghadapi kesulitan pemahaman selama kuliah. Sementara itu, ketika subjek hilang konsentrasi mereka selama kuliah, mayoritas $(73 \%)$ menyatakan bahwa mereka akan memulihkan konsentrasi mereka dengan benar jauh.

\section{Strategi Pemecahan Masalah}

Pemecahan masalah adalah metode penyelidikan. Ini merupakan pendekatan penting untuk menemukan solusi atas suatu masalah. Untuk membantu taruna menjadi pembelajar bahasa yang efektif, adalah penting bahwa kemampuan pemecahan masalah mereka ditingkatkan. Analisis kuesioner mengungkapkan bahwa subjek sering menggunakan strategi pemecahan masalah dalam mengatasi kesulitan pemahaman ketika mereka mendengarkan ceramah dalam bahasa Inggris. Hasil dari strategi ini diringkas di Tabel 6:

Tabel 6. Strategi Pemecahan Masalah

Table 6: Problem-solving Strategies

\begin{tabular}{lc}
\hline Item & $\begin{array}{c}\text { Perc } \\
\text { enta } \\
\text { ge } \\
(\%)\end{array}$ \\
\hline I use words I understand to guess the meaning of the words I do not understand. & 85 \\
I use the general idea of the text to help me guess the meaning of the words that I do not understand. & 79 \\
I use my experience and knowledge to help me understand a lecture. & 83 \\
When I guess the meaning of a word, I think back to everything else that I have heard, to see of my guess makes sense. & 74 \\
As I listen to a lecture, I compare what I understand with what I know about the topic. & 79 \\
As I listen to a lecture, I quickly adjust my interpretation if I realise that it is not correct. & 58 \\
\hline
\end{tabular}

Tabel di atas menunjukkan bahwa strategi pemecahan masalah yang paling banyak digunakan adalah menggunakan kata-kata yang diketahui subjek untuk ditebak arti kata yang tidak dikenal (85\%). Strategi ini juga yang paling banyak digunakan dari semua item yang tercantum dalam daftar pertanyaan. Strategi pemecahan masalah lain yang digunakan subyek adalah menggunakan pengalaman mereka sebelumnya dan pengetahuan untuk membantu mereka memahami kuliah (83\%) serta menggunakan ide umum dari teks untuk membantu mereka menebak arti kata-kata yang tidak mereka pahami (79\%). Wawancara dengan subjek sepertinya mendukung penemuan-penemuan ini:

S1: "Ketika saya tidak tahu kata yang dikatakan dosen, saya hanya mencoba untuk berpikir tentang topiknya."

S4: "Jika dosen mengatakan sesuatu yang saya tidak tahu, saya mencoba menebak maknanya dengan apa yang dia katakan sebelumnya. Kadang kadang aku dapat memahaminya (ketika saya menggunakan strategi ini) "

Untuk membantu pemahaman kuliah, subjek juga menggunakan strategi pemecahan masalah lainnya seperti membandingkan apa yang mereka pahami dengan apa yang mereka ketahui tentang topik (79\%) dan memikirkan kembali hal-hal yang mereka miliki belajar untuk memeriksa bahwa mereka telah menebak arti dari sebuah kata dengan benar (74\%). Namun, analisis itu juga mengungkap bahwa hanya sebagian kecil dari subyek (58\%) menyesuaikan interpretasi mereka ketika mereka menyadari bahwa mereka memilikinya menebak dengan salah. S3: "Saya hanya melihat apa yang saya tahu, karena kadang-kadang, kami telah mempelajari topik di sekolah"

S2: "Jika saya pikir saya salah, saya tidak punya masalah menyesuaikan dengan apa yang dikatakan dosen ..." 


\section{KESIMPULAN}

Hasil dari penelitian ini mengungkapkan bahwa taruna tingkat pertama tahun pertama menghadapi kesulitan untuk memahami mendengarkan dalam bentuk ceramah yang disampaikan dalam bahasa Inggris. Mereka juga menghadapi tantangan dalam mempertahankan konsentrasi selama kuliah, namun, banyak taruna yang tidak menyadari bahwa ada strategi yang dapat mereka terapkan untuk membantu mereka memahami ceramah dengan lebih baik dan lebih efektif. Triangulasi dari tanggapan subyek yang diperoleh melalui kuesioner dan wawancara, ditemukan bahwa meskipun taruna tidak merasa bahwa mendengarkan lebih sulit daripada kemampuan bahasa lainnya, mereka menghadapi kesulitan dalam memahami kuliah yang disampaikan dalam bahasa Inggris. Dapat juga disimpulkan bahwa taruna menggunakan strategi seperti menggunakan pengetahuan awal mereka untuk memahami kuliah dan fokus lebih keras ketika mereka memiliki masalah mempertahankan konsentrasi. Wawancara juga menunjukkan bahwa hambatan yang paling umum dalam memahami kuliah adalah untuk mempertahankan konsentrasi selama periode waktu. Wawancara juga mengungkapkan bahwa banyak taruna menggunakan strategi metakognitif tanpa menyadari bahwa mereka memanfaatkannya. Ini mungkin karena fakta itu sekolah tidak mengajarkan strategi taruna tentang cara mendengarkan ceramah yang panjang. Ini membuktikan pemahaman itu masalah di antara taruna memang ada dan perlu ditangani oleh para profesional ESL.

\section{Implikasi pedagogi}

Meskipun penelitian ini dilakukan sebagai studi kasus, informasi yang diperoleh berharga untuk ESL profesional serta penelitian di bidang strategi pembelajaran. Temuan ini juga memiliki implikasi pada konten dosen. Profesional ESL memiliki peran penting dalam membantu taruna menghadiri kuliah di kelas bahasa kedua. Ketika taruna-taruna ini menghadapi kesulitan dalam memahami ceramah dalam bahasa Inggris, pelatihan pra-sesi atau di program sesi harus diberikan kepada taruna. Pelatihan harus mempersiapkan taruna dengan bahasa dan keterampilan mendengarkan yang diperlukan bagi taruna untuk memahami kuliah secara efektif. Program pelatihan harus menekankan pada memaparkan taruna untuk strategi metakognitif untuk memaksimalkan pemahaman kuliah. Untuk memastikan pemahaman taruna, dosen harus mengevaluasi kembali pendekatan mereka dan mempertimbangkannya kesulitan dan masalah taruna yang menghambat pemahaman kuliah mereka. Pertama, dosen tidak boleh berasumsi bahwa taruna dapat dengan mudah memahami isi ceramah tanpa terlebih dahulu mendapatkan latar belakang yang diperlukan pengetahuan tentang topik. Oleh karena itu, kuliah harus memberikan latar belakang pengetahuan tentang topik yang disajikan sebelum kuliah utama. Ini bisa dalam bentuk catatan kuliah atau diskusi pra-sesi.

\section{DAFTAR PUSTAKA}

Anderson, A. and Lynch, T. (1988). Listening . Oxford University Press, Oxford.

Benson, M. (1989). The academic listening task: A case study. TESOL Quarterly, 23 , 421-445.

Benson, P. (1994) 'Self-access systems as information systems: questions of ideology and control'. In D. Gardner and L. Miller (eds .) Directions in Self-access Language Learning, Hong Kong University Press, 3-12.

Blau, EK, (1990), "The effect of syntax, speed and pauses on listening comprehension", TESOL Quarterly, 24, 746 - 753. 